\title{
PEMEROLEHAN BAHASA ANAK (KAJIAN MEAN LENGTH OF UTTERENCE 'MLU') LUZCA FORTUNATA ROITO SITUMORANG (ANAK USIA SATU TAHUN SEBELAS BULAN)
}

\author{
MARIA SIMANJUNTAK \\ Universitas Negeri medan \\ mariasimanjuntak0@gmail.com
}

\begin{abstract}
Abstrac
This research was carried out on a child aged one year eleven months. This kid named Luzca Fortunata Roito Situmorang son of Mr M.Situmorang and Mrs. E. Nadeak.

The study was conducted to see the child's ability to speak with a single word, two words, three words, four words and five words. This study used a technique re research sean Length of Unterenncce (MLC).

Data collected by recording the words delivered by the child using the method used Mobile tapping method and record then the tape is written and tapping. Way analysis by looking morpheme and syntax used by children.

From the results research that the language skills of the child is very high. So the authors concluded that children who are very intelligent in speaking.
\end{abstract}

Keyword : Language acquisition, Mean Length of Unterenncce (MLC), morpheme, syntax

\section{Abstrak}

Penelitian ini dilakukan pada seorang anak yang berusia satu tahun sebelas bulan. Anak ini bernama Luzca Fortunata Roito Situmorang anak dari Bapak M.Situmorang dan Ibu E. Br. Nadeak.

Penelitian dilakukan untuk melihat kemampuan anak tersebut dalam berbicara dengan menggunakan satu kata, dua kata, tiga kata, empat kata dan lima kata. Penelitian ini menggunakan teknik kajia Mean Length of Unterenncce (MLC).

Teknik pengumpulan data dilakukan dengan cara merekam kata-kata yang disampaikan oleh si anak dengan menggunakan Handphone metode yang dipakai metode sadap dan catat kemudian hasil rekaman dituliskan dan dianalisis.Cara menganalisis dengan melihat morfem dan sintaksis yang dipakai oleh anak.

Dari hasil penelelitian diketahui bahwa kemampuan berbahasa si anak tersebut sangat tinggi. Sehingga penulis menyimpulkan bahwa anak tersebut sangat cerdas dalam berbicara.

Kata kunci : Pemerolehan bahasa, Mean Length of Unterenncce (MLC),morfem, sintaksis 


\section{PENDAHULUAN}

\subsection{Latar Belakang Masalah}

Proses pemerolehan bahasa pada anak-anak merupakan satu hal yang perlu diteliti lebih mendalam. Bagaimana manusia memperoleh bahasa merupakan satu masalah yang amat mengagumkan dan sukar dibuktikan? Berbagai teori dari bidang disiplin yang berbeda telah dikemukakan oleh para pengkaji untuk menerangkan bagaimana proses ini berlaku dalam kalangan anak-anak. Memang diakui bahwa disadari ataupun tidak, sistem-sistem linguistik dikuasai dengan pantas oleh individu kanak-kanak walaupun umumnya tidak dalam pengajaran formal. Pemerolehan bahasa merupakan satu proses perkembangan bahasa manusia. Ada dua proses yang terlibat dalam pemerolehan bahasa dalam kalangan anak, yaitu pemerolehan bahasa dan pembelajaran bahasa.

Dua faktor utama yang sering dikaitkan dengan pemerolehan bahasa ialah faktor nurture dan faktor nature.Nature merupakan pemerolehan bahasa yang sudah ada sejak lahir sedangkan nurture merupakan pemerolehan bahasa yang dipengaruhi oleh lingkungan secara alami. Bayi-bayi yang baru lahir sudah mulai mengenal bunyi-bunyi yang terdapat di sekitarnya. Brookes (dalam Yusoff, 1995:456) mengatakan bahwa pemerolehan bahasa dalam bentuk yang paling sederhana bagi setiap bayi bermula pada waktu bayi itu berumur lebih kurang 18 bulan dan mencapai bentuk yang hampir sempurna ketika berumur lebih kurang empat tahun. Menurut Simanjuntak (1982) pemerolehan bahasa bermaksud penguasaan bahasa oleh seseorang secara tidak langsung dan dikatakan aktif berlaku dalam kalangan anakanak dalam lingkungan umur 2-6 tahun.

Pemerolehan bahasa dikaitkan dengan penguasaan sesuatu bahasa tanpa disadari atau dipelajari secara langsung, yaitu tanpa melalui pendidikan secara formal untuk mempelajarinya. Pengkajian tentang pemerolehan bahasa sangat penting terutamanya dalam bidang pengajaran bahasa. Pengetahuan yang cukup tentang proses dan hakikat pemerolehan bahasa akan membantu menentukan keberhasilan dalam bidang pengajaran bahasa.

Pemerolehan bahasa pertama ialah bahasa yang pertama kali dikuasai oleh anak yang biasa disebut bahasa ibu. Setiap anak yang normal pada usia di bawah lima tahun dapat berkomunikasi dalam bahasa yang digunakan di lingkungannya, walaupun tanpa pembelajaran formal. Dalam usia ini pada umumnya anak-anak telah menguasai sistem fonologi, morfologi, sintaksis, dan semantik dari bahasa pertamanya. Penguasaan atau perkembangan bahasa anak diperoleh secara bertahap.Salah satu perkembangan bahasa yang khas dialami anak adalah perkembangan sintaksis. 
Pada periode awal anak menggunakan kalimat satu kata, kalimat dua kata, kalimat tiga kata, dan seterusnya sampai tahap kalimat lengkap strukturnya (agentaction-object-location). Jumlah elemen yang mengandung arti dalam kalimat yang diucapkan anak dapat dapat diukur denganMean Length of Utterance $(M L U)$. MLU merupakan satu konsep yang digunakan untuk mengukur produk linguistik yang dihasilkan oleh seseorang anak. Secara umum, penghitungan $M L U$ dilakukan dengan membagi bilangan morfem dengan bilangan ujaran. Artinya, jumlah bilangan ujaran yang diperlukan ialah 50 atau 100 ujaran utama anak. Semakin tinggi $M L U$ anak maka semakin tinggilah penguasaan berbahasa anak tersebut.

\subsection{Rumusan Masalah}

Berdasarkan latar belakang masalah di atas, rumusan masalah penelitian ini adalah bagaimana perkembangan bahasa pertama anak usia 1 tahun 11 bulan berdasarkan pengukuran $M L U$ ?

\subsection{Tujuan Penelitian}

Berdasarkan rumusan masalah di atas, tujuan penelitian ini adalah untuk mengetahui perkembangan bahasa pertama anak usia 1 tahun 11 bulan berdasarkan pengukuran $M L U$.

\section{TINJAUAN PUSTAKA}

\subsection{Pemerolehan Bahasa Pertama}

Pemerolehan bahasa atau akuisisi adalah proses yang berlangsung di dalam otak seorang anak ketika dia memeroleh bahasa pertamanya atau bahasa ibunya. Pemerolehan bahasa biasanya dibedakan dari pembelajaran bahasa (language learning). Pembelajaran bahasa berkaitan dengan proses-proses yang terjadi pada waktu seorang kanak-kanak mempelajari bahasa kedua setelah dia mempelajari bahasa pertamanya. Jadi, pemerolehan bahasa berkenaan dengan bahasa pertama, sedangkan pembelajaran bahasa berkenaan dengan bahasa kedua.

Setiap anak yang normal akan belajar bahasa pertama (bahasa ibu) dalam tahun-tahun pertamanya dan proses itu terjadi hingga kira-kira umur lima tahun (Nababan, 1992:72). Dalam proses perkembangan, semua anak manusia yang normal paling sedikit memperoleh satu bahasa alamiah. Dengan kata lain, setiap anak yang normal atau mengalami pertumbuhan yang wajar memperoleh sesuatu bahasa, yaitu bahasa pertama atau bahasa ibu dalam tahun-tahun pertama kehidupannya, kecuali ada gangguan pada anak tersebut. 
Proses pemerolehan bahasa merupakan suatu hal yang kontroversial antara para ahli bahasa. Permasalahan yang diperdebatan antara para ahli adalah pemerolehan bahasa yang bersifat nuture dan nature (Dardjowidjojo, 2010:235). Ahli bahasa yang menganut aliran behaviorisme mengatakan bahwa pemerolehan bahasa bersifat nurture, yakni pemerolehan ditentukan oleh alam lingkungan. Ahli bahasa lain mengatakan manusia dilahirkan dengan suatu tabula rasa, yakni semacam piring kosong tanpa apa pun. Piring tersebut kemudian diisi oleh alam termasuk bahasany

Berbeda dengan ahli-ahli bahasa tersebut, Chomsky berpandangan bahwa pemerolehan bahasa tidak hanya didasarkan pada nurture, tetapi nature. Anak tidak dilahirkan sebagai piring kosong atau tabula rasa, tetapi anak telah dibekali dengan sebuah alat yang dinamakan peranti pemerolehan bahasa. Setiap anak terbukti memiliki kesamaan dalam pemerolehan bahasa dan melewati proses yang sama dalam menguasai bahasa masing-masing. (Dardjowidjojo, 2010:236).

Kontroversi tersebut terus berlanjut walaupun sebagian ahli ada yang sependapat dengan Chomsky, tetapi faktor nurture juga tidak dapat dikesampingkan begitu saja. Nature diperlukan karena bekal kodrati makhluk tidak mungkin dapat berbahasa. Nurture juga diperlukan karena tanpa adanya input dari alam sekitar bekal yang kodrati itu tidak akan terwujud.

\subsection{Perkembangan Sintaksis}

Pemerolehan sintaksis pada anak-anak dimulai pada usia kurang dari 2:0 tahun. Pada usia tersebut anak sudah bisa menyusun kalimat dua kata atau lebih two word utterance 'Ujaran Dua Kata' (UDK). Anak mulai dengan dua kata yang diselingi jeda sehingga seolah-olah dua kata itu terpisah. Dengan adanya dua kata dalam UDK maka orang dewasa dapat lebih bisa menerka apa yang dimaksud oleh anak karena cakupan makna menjadi lebih terbatas. UDK sintaksisnya lebih kompleks dan semantiknya juga semakin jelas (Dardjowidjojo, 2010:248). Ciri lain dari UDK adalah kedua kata tersebut adalah kata-kata dari kategori utama, yaitu nomina, verba, adjektiva, dan adverbia.

Menurut Brown (dalam Dardjowidjojo, 2010:249) anak usia 2;0 telah menguasai hubungan kasus-kasus dan operasi-operasi seperti pelaku-perbuatan (FNFV), pelaku-objek (FN-FN), p erbuatan-objek (FV-FN), perbuatan-lokasi (FV-FAdv), pemilik-dimiliki (FN-FV), objek-lokasi (FN-FAdv), atribut-entitas, nominative, minta ulang, tak-ada lagi. Walaupun, maknanya sudah jelas tetapi setiap ujaran anak harus disesuaikan dengan konteksnya

\subsection{Pengukuran Mean Length of Utterance (MLU)}


$M L U$ merupakan pengukur untuk perkembangan sintaksis anak. Menurut Brown (dalam Dardjowidjojo, 2010:241) cara menghitung $M L U$ dapat dilakukan dengan beberapa langkah, pertama mengambil sampel sebanyak 100 ujaran. Kedua, menghitung jumlah morfemnya. Ketiga, membagi jumlah morfem dengan jumlah ujaran, seperti pada rumus berikut.

Jumlah morfem

$M L U=$

Jumlah tuturan

Brown (dalam Owens, 2008) membagi tahap pemerolehan bahasa anak berdasarkan MLU anak menjadi sepuluh tahap, yaitu :

1. Tahap I MLU $(1-1,5)$ pada usia $12-22$ bulan

2. Tahap II $M L U(1,5-2,0)$ pada usia $27-28$ bulan

3. Tahap III $M L U(2,0-2,25)$ pada usia $27-28$ bulan

4. Tahap IV $M L U(2,25-2,5)$ pada usia 28 - 30 bulan

5. Tahap V MLU $(2,5-2,75)$ pada usia $31-32$ bulan

6. Tahap VI $M L U(2,75-30,0)$ pada bulan biasa 33-34 tahun

7. Tahap VII $M L U(3,0-3,5)$ pada usai $35-39$ bulan

8. Tahap VIII $M L U(3,5-3,45)$ pada usia 38-40 bulan

9. Tahap IX $M L U(3,5-3,45)$ pada usia 41-46 duluan

10. Tahap X $M L U(45+)$ pada usia +47 bulan.

\section{METODOLOGI PENELITIAN}

\subsection{Data dan Sumber Data Penelitian}

Sumber data penelitian ini adalah anak perempuan usia 1 tahun 11 bulan. Anak tersebut bernama Luzca Fortunata Roito Situmorang. Bahasa yang digunakan anak tersebut adalah bahasaIndonesia. Bahasa tersebut merupakan bahasa pertamanya atau bahasa ibunya. Anak tersebut tinggal bersama orang tuanya. Ayahnya berprofesi sebagai wirausaha sedangkan ibunya berprofesi sebagai perawat. Dilahirkan di Medan, 2 Juni 2014. Sehari-hari anak tersebut ikut dengan orang tuanya di rumah dan sering berkomunikasi dengan para tetangga. Data yang dikumpulkan berupa rekaman tuturan anak tersebut dengan orang tuanya. Data direkam dengan handphone. 


\subsection{Teknik Pengumpulan Data}

Data penelitian dikumpulkan melalui hasil rekaman tuturan anak. Alat yang digunakan untuk merekam adalah hanphone. Hasil rekaman ditranskripkan dengan ejaan fonemik dan diartikan ke dalam bahasa Indonesia. Data yang dikumpulkan hanyalah sebanyak 100 tuturan anak yang diambil sebagai sampel untuk mengukur $M L U$ anak tersebut. Data diambil dari tanggal 2-10 Mei 2016. Lokasi perekaman dilakukan di rumah keluarga M.Situmorang dan M. Br. Nadeak.

\subsection{Teknik Analisis Data}

Aspek linguistik yang dianalisis dalam kajian ini ialah sintaksis. Analisis akan dilakukan secara kualitatif dan kuantitatif. Kaedah kuantitatif melibatkan analisis distribusi dan perkiraan $M L U$ sebagai satu kaedah menentukan perkembangan bahasa anak tersebut. Penganalisisan data dapat dilakukan dengan empat langkah, yaitu:

1. Pentranskripsian Data

2. Tuturan yang direkam melalui handphone ditranskrisikan dalam bentuk kalimat. Data yang terkumpul tersebut disusun dalam bentuk stuktur kalimat tuturan anak.

3. Penyeleksian Data

Data yang telah ditransipsikan diolah dengan memisahkan data yang dibutuhkan dan memenuhi syarat yang sesuai dengan tujuan penelitian. tuturan anak yang diseleksi adalah tuturan yang memenuhi syarat untuk dihitung $M L U$-nya.

4. Pengklasifikasian Data

Data yang telah diseleksi sesuai dengan tujuan penelitian dan data yang dapat dihitung $M L U$-nya. Cara mengklasifikasikan data tersebut adalah dengan mengelompokkan tuturan anak berdasarkan jumlah morfem setiap tuturan. Selanjutnya, jumlah morfem setiap tuturan dijumlahkan (jumlah ujaran dibatasi hanya sampai 100 ujaran). Kemudian, jumlah morfem dari 100 tuturan tersebut dibagi dengan 100

5. Pemaparan Hasil Analisis Data

6. Setelah diketahui hasil $M L U$, hasil tersebut dianalisis untuk mengetahui anak yang menjadi sampel penelitian berarada pada tahap apa dan menganalisis pemerolehan sintaksis dari segi panjang tuturan dan struktur sintaksis. Struktur sintaksis seperti jenis kata yang telah diperoleh dan pola kalimat diperoleh.

\section{PEMBAHASAN}

\subsection{Hasil Penelitian}


Hasil rekaman tuturan anak yang telah ditranskripsikan ke ejaan fonetik yang diartikan ke dalam bahasa Indonesia.

\section{Kalimat Satu Kata}

1. Ndak 'tidak'

2. Indak... 'tidak...'

3. ucak'rusak'

4. guguk 'Anjing'

5. antik 'cantik'

6. pigi 'pergi'

7. keta 'sepeda motor'

8. Aloo 'halo'

9. Cini 'sini'

10. Edas' pedas'

11. Lya 'iya'

12. Mati 'mati'

13. Mama 'mama'

14. Num 'minum'

15. Kakak 'kakak'

16. Ha? 'apa?'

17. Datang 'datang'

18. Busuk 'busuk'

19. Patu 'sepatu'

20. Ndi 'mandi'

\section{Kalimat Dua Kata}

21. Bou kakak 'namboru kakak ( Namboru panggilan untuk saudara perempuan ayah)

22. Papa olang 'bapak orang'

23. Mama igi 'mama pergi'

24. Dedek sayang 'adek sayang'

25. Jangan bawa 'jangan bawa'

26. Alon kempis 'balon kempes'

27. Opi bulat 'topi bulat'

28. Patu kakak 'sepatu kakak'

29. Tas cekolah 'tas sekolah'

30. Lari ia 'lari dia'

31. Abang nakal 'abang nakal'

32. Cicak dinding 'cicak di dinding' 
33. Satu satu 'satu satu'

34. Cicak-cicak merapaya 'cicak-cicak merayap'

35. Kupu-kupu belang 'kupu-kupu bilalang'

36. Kakak ndi ma 'kakak mandi mama'

37. Lah mati 'sudah mati'

38. Ya ucak 'yah rusak'

39. Mama kakak 'mama kakak

40. Opung kakak' nenek kakak

41. Tu mama 'itu mama'

42. Kakak num 'kakak minum

\section{Kalimat Tiga Kata}

43. tu dedek bou 'itu adik, namboru'

44. gigit nyamuk akit 'digigit nyamuk sakit'

45. kakak mau bobok 'kakak mau tidur'

46. balon kakak anak 'balon kakak banyak'

47. opi saya bundar 'topi saya bundar'

48. Dedek sayang kakak 'adek sayang kakak'

49. Mama mau erja ' mama mau kerja

\section{Kalimat Empat Kata}

50. Kakak gigik ape na 'kakak gigit hp ini!'

51. Bang ada ucing bobo 'abang ada kucing tidur'

52. Mama bobo I amar 'Mama tidur di kamar'

53. Mama ulang ita umah ' mama pulang kita ke rumah'

Kalimat Lima Kata

54. Kakak mau num madu bou ' kakak mau minum teh dengan madu'

55. Aduh ucak lagu kakak na' aduh rusak lagu kakak ini

\subsection{Pembahasan}

Tabel 1 Analisis Panjang Tuturan

\begin{tabular}{|l|l|l|}
\hline Jumlah Kata Per Tuturan & Jumlah Tuturan & Jumlah Morfem \\
\hline Kalimat satu kata & 20 & 26 \\
\hline Kalimat dua kata & 21 & 42 \\
\hline
\end{tabular}




\begin{tabular}{|l|l|l|}
\hline Kalimat tiga kata & 7 & 21 \\
\hline Kalimat empat kata & 4 & 16 \\
\hline Kalimat lima kata & 2 & 10 \\
\hline Total & 54 & 115 \\
\hline
\end{tabular}

$M L U=\frac{\text { Jumlah morfem }}{\text { Jumlah tuturan }}$
$M L U=\frac{115}{54}=\mathbf{2 , 1 3}$

Berdasarkan hasil pengukuran $M L U$ di atas, panjang tuturan Luzca 2,13 kata per tuturan. Bila disesuaikan dengan pendapat Brown, Luzca masih pada tahap III yang berarti pemerolehan bahasa sangat tinggi karena pada usia Luzca baru berusia satu tahun empat bulan. Sedangkan jumlah kemampuan seperti di atas seharusnya anak yang berusia dua tahun tiga bulan.

Berdasarkan data yang diperoleh dan dikelompokkan, Luzca telah mampu bertutur dari kalimat satu kata sampai kalimat lima kata.

Jenis kata yang sudah dikenal Luzca adalah nomina (N), verba (V), Adjektiva (Adj), Adverbia (Adv)

N balon 'balon', keta 'honda', kakak 'kakak'

$\mathrm{V} \quad$ mandi. Bobok, minum

Adj ucak 'rusak', auk ' bau'

Adv Cicak dinding 'cicak di dinding'

Bila dilihat dari pola kalimat, Luzca telah mampu bertutur dengan pola dengan pola dasar seperti FN+FN, FN+FV, FN+FAdj, FN+Adv.

$\mathrm{FN}+\mathrm{FN} \quad$ papa orang 'bapak orang'

$\mathrm{FN}+\mathrm{FV} \quad$ Kakakngomong 'kakak bicara'

FN+FAdj Dedek sayang 'adek sayang'

FN+Adv Cicak dinding 'cicak di dinding

\section{PENUTUP}

\subsection{Simpulan}


Simpulan yang dapat dibuat berdasarkan dapatan analisis terhadap Luzca yang berusia 1 tahun 11 bulan adalah sebagai berikut.

1. Analisis tuturan menunjukkan Luzca mempunyai $M L U 2,13$ berada pada tahap III yang berarti berada pada tahap tinggi. Jenis kata yang telah diperoleh dan dituturkan oleh Luzca antara lain nomina, verba, adjektiva, dan adverbia.

2. Luzca telah mampu bertutur dari kalimat satu kata sampai kalimat lima kata yang berarti telah mampu bertutur kalimat lengkap.

3. Luzca telah mampu bertutur membentuk pola kalimat dasar, seperti $\mathrm{FN}+\mathrm{FN}$, FN+FV, FN+FAdj, FN+FAdv.

\subsection{Saran}

Pemerolehan bahasa pada setiap anak berbeda satu dengan yang lain. Ada banyak cara yang kita lakukakan untuk merangsang daya bicara seoarng anak adalah dengan memutar CD lagu anak anak. Kemampuan anak mengikuti irama lagu turut membantu meningkatkan kemampuan berbicara seorang anak, selain hal itu dapat juga kita lakukan dengan mengucapkan bahasa yang sesungguhnya dengan benar, jangan disalah-salahkan.Contoh : Minum bukan Num, makan bukan maam, dan tidur bukan bobok.

\section{DAFTAR PUSTAKA}

Darjowodjojo, Soenjono. 2010. Psikolinguistik: Pengatar Pemahaman Bahasa Manusia. Jakarta: Yayasan Obor Indonesia.

Nababan dan Sri Utari Subyakto. 1992. Psikolinguistik: Suatu Pengatar. Jakarta: Gramedia Pustaka Utama.

Owens, J.E. 2008. Excerpt from Language Development: An Introduction. Dalamhttp://www.education.com/reference/article/acquisitionsentence-form. Diakses tanggal 30 Mei 2011

Simanjuntak, Mangantar. 1982. Pemerolehan Bahasa Melayu: Bahagian Fonologi. Jurnal Dewan Bahasa, Ogos/September, 615-625.

Yusoff, Abdullah dan Che Rabiah Mohamed (1995). Teori Pemelajaran Sosial dan Pemerolehan Bahasa Pertama. Jurnal Dewan Bahasa, Mei. 456-464. 
